\title{
ANALYSIS OF REFORMING THE PENSION SYSTEM OF UKRAINE: IMPLEMENTATION PROBLEMS AND DEVELOPMENT PROSPECTS
}

Formulation of the problem. Pension provision is an element of the pension system that ensures sustainable socio-economic development of the state as a whole. In today's conditions, the issue of reforming the pension system of Ukraine in order to increase the level of social security of citizens and protection from financial and economic troubles is becoming relevant. Ukraine's pension system has been operating in its current form since 2004 and formally consists of three levels of pension provision. The three-tier pension system will allow to distribute between its components the risks associated with changes in the demographic situation and with fluctuations in the economy and capital market.

This distribution of risks will make the pension system more financially balanced and sustainable, which insures employees against lowering the overall level of income after retirement.

Characterizing the demographic situation of the country, it should be noted that today the birth rate is too low, and the migration of able-bodied people has increased significantly. The share of pensioners in the total population is $26 \%$, and by 2050 it will increase to $38 \%$, i.e., there are 4 pensioners per 10 working people, in the future the forecast ratio will be $10: 8$. [1].

Thus, the high level of demographic burden on the working population, the presence of a significant number of working benefits to pay contributions to the Pension Fund of Ukraine and low wages, which in one third of workers is not higher than the subsistence level, currently cause imbalance of the solidarity system. pension insurance systems and the development of private pension provision.

Raising the minimum old-age pension to the subsistence level, which is not in line with wage growth and the real financial capabilities of the Pension Fund of Ukraine, may lead to a financial crisis in the pension system [1].

The existing problems of pension provision of citizens actualize the topic of this study and will allow to focus attention on the strategic direction of reforming the pension system of Ukraine.

Analysis of recent research and publications. The issue of reforming the pension system was covered in the research of such domestic scientists as: O. Vysh- nevska, who paid great attention to the analysis of international experience in reforming the pension system [1].

In her works, she analyzes the experience of European countries in reforming the pension system in the context of the possibility of its application in the realities of modern Ukraine; considers the pension systems of individual EU countries, which are based on three-tier models, which include a solidarity-distribution scheme with a basic level of pension and accumulative and are combined in different versions; Determines that for all countries of the European Union, one of the most painful issues of pension reform is the issue of retirement age, as it affects the interests of several generations of current and future retirees.

The general tendency to increase the retirement age, the author proposes to be under the influence of a number of demographic, economic and social factors. The author's position on the development of Ukraine's pension system is that for our country further study of the experience of European countries and successful design solutions will be useful for their application in building and reforming their own pension system, which will avoid negative trends due to socio-economic realities of modern society.

M. Grabovska and V. Zaika, who in their works carefully studied the organization and activities of private pension funds [2] noted the following: the definition of the term "accumulative pension system" and the mechanism of legal regulation of the accumulative pension system; the expediency of paying attention to the possibility of applying different doctrinal approaches to the explanation of the concepts of the accumulative pension system and the application of the legal mechanism to these concepts is emphasized; also proved the need to finalize our Ukrainian legislation for the viability of the funded pension system as a private pension fund, and, as an alternative to the solidarity pension system, in today's world. R. Picus, A. Chemistry in the works of which the issue of reforming the pension insurance system was studied was noted in the following [3]. Namely: the study reveals the factors that determine the structural pension reform in Europe, and the possibility of its implementation in Ukraine; the historical stages of origin and development of pension insurance in the world are determined; two main models of pension systems have 
been identified; the change of economic opinion of leading European scientists on pension insurance under the influence of time and transformations in economy is considered; the reasons on the basis of which in the postwar period the reform of pension insurance systems in Europe took place are studied; the history of the emergence of the first accumulative programs and the creation of private pension insurance, which led to structural reforms in Western Europe; various factors influencing the probability of structural pension reform in any country and the possibility of such a reform in Ukraine are studied.

Also, recently the process of pension reform is actively covered in publications in periodicals. The works of E. Libanova, T. Kiryan [4], M. Shapoval [5] are devoted to the study of pension system reform in terms of the introduction of the accumulative component. In the works of these authors the perspective directions of reforming the national pension system, ways of strengthening the stimulating role in the pension system, the impact of the introduction of the accumulative component of the state pension insurance system on increasing the level of social protection in Ukraine are considered.

The specific features of the national pension systems of different countries, the world experience of reforming the social sphere are described in detail in the works of these famous scientists. At the same time, there are still no established positions on the methodological basis for the introduction of the cumulative level - from the timing to the form and models of the cumulative component.

Selection of previously unsolved parts of the overall problem. Given the great theoretical and practical value of the work of scientists, the problems of the pension system remain insufficiently studied, in particular the achievement of strategic goals and objectives of reform.

The purpose of the article. Research of problems of realization of reforms of pension system of Ukraine and outline of prospects of its further development for achievement of strategic purposes and tasks of reforming.

The contribution of the main research material. The deterioration of the socio-economic situation in Ukraine, at present, has dramatically changed the lives of the population and led to a deepening stratification of society in terms of income, as a consequence: to differentiate the living standards of the population.

Pension provision is the main form of social protection system. According to the Law of Ukraine "On Pension Provision", citizens of Ukraine are entitled to state pension provision by age, disability, in connection with the loss of a breadwinner and in other cases provided by this law. The share of retirees is 28.6 percent of the total population. The share of pension benefits reached 43 percent in total social transfers (social assistance and benefits from all sources of funding) and 21 percent in total household income.
The pension reform, which began in 2004, envisages the replacement of the current pension system with a modern three-tier insurance system.

The strategy for the development of the pension system in recent years has been aimed at changing the retirement age according to life expectancy; transfer of pension receipt through bank institutions; transfer of certain categories of pensions from the solidarity system to non-state pension funds; replenishment of PFC by registration of labor relations; reduction of underemployment and unemployment; increase in pension benefits, recalculation of the amount of pension provision for working pensioners.

However, the high level of demographic burden on the working population, the presence of a significant number of working benefits to pay contributions to the Pension Fund of Ukraine and low wages, which in one third of workers is not higher than the subsistence level, currently lead to an imbalance of the solidarity system. maintenance of the introduction of the accumulative pension insurance system and the development of private pension provision. Thus, the system of social protection in the context of transformation and reform of pensions has faced two different but major problems: the need to reduce poverty and the need to obtain financial resources for social purposes from the budget in the context of rising GDP and national income. Increasing the minimum old-age pension to the subsistence level, which is not consistent with the growth of wages and the real financial capabilities of the Pension Fund of Ukraine, may lead to a financial crisis of the pension system [3].

The state is trying to modernize the provision of minimum social benefits to the living standards of pensioners. Stages of reforming the pension system in Ukraine in recent years are aimed at people of retirement age to a fair and better life (Table 1).

Today, the priority tasks in the field of social protection and social security are to increase the efficiency of budget management. The legislation provides for the transition to the funded pension system from January 1 , 2019, but the reform has not been implemented, as the IMF has recommended to refrain from plans to launch a funded pension system in 2019.

This recommendation is based on the fact that this reform will lead to a decrease in revenues to the Pension Fund, and a lack of funds in the 2019 state budget.

According to the Law of Ukraine №2148 "On Amendments to Certain Legislative Acts of Ukraine Concerning Pension Increase" (2017), the pension system should consist of:

- mandatory level;

- mandatory-accumulative level;

- voluntary-accumulative level.

The main direction of the savings system is to receive funds, mandatory contributions to the pension system, which in turn will be invested in the country's economy. 
Stages of reforming the pension system in Ukraine for 2019-2020

\begin{tabular}{|c|c|c|c|c|c|}
\hline Name of pension & \multicolumn{2}{|c|}{2019 year } & \multicolumn{2}{c|}{2020 year } & Period 2019-2020 \\
\hline Retirement age, years & 60 & 65 & 60 & 65 & $\begin{array}{c}\text { From January 1 } \\
\text { to December 31 }\end{array}$ \\
\hline $\begin{array}{c}\text { Insurance experience, } \\
\text { years }\end{array}$ & 26 & $\begin{array}{c}\text { from 15-16 } \\
\text { years }\end{array}$ & 27 & from 15-20 & $\begin{array}{c}\text { From January 1 } \\
\text { to December 31 }\end{array}$ \\
\hline Minimum pension, UAH & 1497,00 & 1564,00 & 1712,00 & & From January 1 \\
\hline $\begin{array}{c}\text { Maximum pension, UAH } \\
14970,00 \\
15640,00 \\
16380,00\end{array}$ & & $\begin{array}{c}16980,00 \\
17120,00 \\
17690,00\end{array}$ & 1769,00 & $\begin{array}{c}\text { From January 1 } \\
\text { From July 1 } \\
\text { From December 1 }\end{array}$ \\
\hline $\begin{array}{c}\text { Amount of contributions } \\
\text { to the solidarity system } \\
\text { (to the PFU) }\end{array}$ & 22033,44 & - & - & - & From January 1 \\
\hline $\begin{array}{c}\text { Wages for calculating } \\
\text { pensions, UAH }\end{array}$ & 4173,00 & 9205.19 av- & 4723.00 & 9546,32 & $\begin{array}{c}\text { Minimum and average } \\
\text { from January 1 for the } \\
\text { whole year }\end{array}$ \\
\hline $\begin{array}{c}\text { One-time payment, UAH } \\
\text { erage salary }\end{array}$ & 2410,17 & - & 1000,00 & - & $\begin{array}{c}\text { From January 1 } \\
\text { to December 31 }\end{array}$ \\
\hline Indexing pension, \% & 100,00 & 14000,00 & 173,05 & 1600,00 & From January 1 \\
\hline Enumeration pension & 322,2 & $85 \%$ & 43,7 & $75 \%$ & From January \\
\hline $\begin{array}{c}\text { Working retirees, million } \\
\text { UAH }\end{array}$ & 2,5 & - & 2,7 & - & From January 1 \\
\hline
\end{tabular}

* Built by the authors on the basis of sources $[2 ; 3]$.

The introduction of an accumulative system will be most useful for those who are currently 30-35 years old. Under this system, citizens over the age of 40 will be required to set aside at least $10 \%$ of their income. Citizens aged 18-35 will become mandatory depositors in the savings system. The percentage of contributions to the mandatory savings system of the single insurance contribution will be $2-7 \%$ and will increase annually by $1 \%$.

However, the issue of pension system development is becoming even more acute, it is necessary to assess the impact of pension reforms on the insurance and banking market, so as not to worsen the conditions of their activities and competition.

As part of the pension reform, starting from January 1, 2018, the appointment of a pension at the age of 60 requires the presence of insurance experience with current accrual.

These changes took place after the entry into force of the 2019 reform, in accordance with Art. 1 part 26 of the Law of Ukraine "On compulsory state insurance" from 01.01.2019 the right to a pension (Table 2).

Insurance length of service required for retirement by age *

\begin{tabular}{|c|c|c|c|}
\hline \multirow[t]{2}{*}{ Retirement period } & \multicolumn{3}{|c|}{ Age } \\
\hline & 60 years & 63 years & 65 years \\
\hline 1 & 2 & 3 & 4 \\
\hline $\begin{array}{c}\text { With } 01.01 .2019 \text { year } \\
\text { to } 31.12 .2019 \\
\end{array}$ & No less 26 years & From 16 to 26 years & From 15 to 16 years \\
\hline With 01.01 .2020 to 31.12 .2020 & No less 27 years & From 17 to 27 years & From 15 to 17 \\
\hline With 01.01 .2021 to 31.12 .2021 & No less 28 years & From 18 to 28 years & From 15 to 18 \\
\hline With 01.01 .2022 to 31.12 .2022 & No less 29 years & From 19 to 29 years & From 15 to 19 \\
\hline With 01.01 .2023 to 31.12 .2023 & No less 30 years & From 20 to 30 years & From 15 to 20 \\
\hline With 01.01 .2024 to 31.12 .2024 & No less 31 years & From 21 to 31 years & From 15 to 21 \\
\hline With 01.01 .2025 to 31.12 .2025 & No less 32 years & From 22 to 32 years & From 15 to 22 \\
\hline With 01.01 .2026 to 31.12 .2026 & No less 33 years & From 23 to 33 years & From 15 to 23 \\
\hline With 01.01 .2027 to 31.12 .2027 & No less 34 years & From 24 to 34 years & From 15 to 24 \\
\hline Starting with 01.01 .2028 year & No less 35 years & From 25 to 35 years & From 15 to 25 \\
\hline
\end{tabular}

* Built by the author on the basis of source [5]. At the same time, it is envisaged that from January 1, 2018. in the absence of the required length of service on the date of reaching the age, an old-age pension may be granted after the person has acquired the required length of service. That is, the availability of the required insurance record is determined on the date of reaching the appropriate age [6]. 
It is worth noting that thanks to the savings system, citizens will be more dependent on personal labor and financial contribution, but independent of the country's demographic situation, wages and subsistence level, which is undoubtedly a positive result.

Thus, the main strategic directions for improving pension reform are the introduction of changes in population demographics; the percentage of SDRs, when accrued for each entrepreneur separately (according to the group of individual entrepreneurs to the type of activity); open your deposit account for the accumulative system in free access; give the opportunity to work to retirees (improve their knowledge in practice, provide the opportunity to work with modern equipment, programs); determine the dates of introduction of the second level and the age category of participants; to establish and increase the work of the pension organization; to show confidence in the reforms of the Pension Fund to the population.

Conclusions and suggestions. Thus, the need for gradual transformation, modernization and reform of the pension system with increasing role of the funded system is due to the main European trends: increasing the revenue side of the budgets of state pension funds by increasing the demographic burden; increase in expenditures for the needs of pension protection, due to increased life expectancy; raising the general standard of living of the population, providing the population of the country with quality medical care, which will reduce the mortality of the population under retirement age.

Therefore, the constant monitoring of the achievement of the strategic goals of the reform of the pension system and pension provision and the adoption of sound decisions regarding the overcoming of strategic gaps is a rather topical issue and needs further research.

\section{Literature}

1. Вишневська О. А. Пенсійна реформа: зарубіжний досвід для України. Аспекти публічного управління. Механізми публічного управління. 2016. № 8 (34). С. 42-48. doi:10.15421/151639. 2. Грабовська Г. М., Заїка В. П. Накопичувальна пенсійна система як складова недержавного пенсійного фонду. Молодий вчений. 2020. № 1 (77). C. 21-25. doi: https://doi.org/10.32839/ 2304-5809/2020-1-77-5. 3. Пікус Р. В., Хемій А. С. Реформування систем пенсійного страхування країн Західної Свропи. Економічний аналіз: зб. наук. праць / Тернопільський національний економічний університет; редкол.: О. В. Ярощук (голов. ред.) та ін. Тернопіль: Видавничо-поліграфічний центр Тернопільського національного економічного університету «Економічна думка», 2017. Т. 27. № 1. C. 131-138. Doi: 10.35774/econa. 4. Кір'ян Т. Підвищення стимулюючої ролі пенсійної системи в Україні. Украӥна: аспекти npaųi. 2006. № 8. С. 15-20. 5. Шаповал М. С., Коцюба О. В., Резнікова Ю. С. Дослідження впливу запровадження накопичувальної складової державної системи пенсійного страхування на підвищення рівня соціального захисту населення в Україні. Соціальний захист. 2005. № 12. С. 34-39. 6. Накопичувальний рівень пенсії: чому це не працює в Україні? Все PRO Гроші. URL: http://vseprogroshi.com.ua/nakopichuvalnijriven-pensi $\%$ D1\%97-chomu-ce-ne-pracyuye-v-ukra $\% \mathrm{D} 1$ \%97ni.html (дата звернення 25.09.2020). 7. Ставерська Т. О., Шевчук. І. Л. Етапи пенсійної реформи в Україні. Економіка $і$ суспільство. 2017. № 13. URL: http://www.economyandsociety.in.ua/journal/13_ukr/204. pdf (дата звернення 25.09.2020). 8. Пенсійна реформа від 15.12.2005 р. №525-p. Кабінет Міністрів України: урядовий портал. URL: https//www.kmu.gov.ua/npas/25 (дата звернення 21.09.2020). 9. Якісні зміни, що відбуваються вже сьогодні. Урядовий портал. URL: https: //www.kmu.gov.ua/diyalnist/reformi (дата звернення 20.09.2020). 10. Пенсійний Фонд України. URL: https: //www.pfu.gov.ua/od/166068-stazh-neobhidnyj-dlya-pryz nachennya-pensiyi-za-vikom/ (дата звернення 21.09. 2020). 11. Мастюгіна Г. Пенсійна реформа: особливості призначення пенсій. URL: http://uteka.ua/ua/ publication (дата звернення 19.09.2020). 12. Мінімальна пенсія на 2019-2020 роки в Україні. URL: https://www/profiwins.com (дата звернення 20.09.2020). 13. Про пенсійне забезпечення: Закон України від 05.11.1991 p. № 1788-XII. URL: https://www/pfu.gov.ua zt13204 (дата звернення 20.09.2020). 14. Реформування соціальної політики в Україні: проблеми та перспективи : навч.-наук. вид. / авт. кол. : В. А. Скуратівський, В. П. Трощинський, П. К. Ситник та ін. ; за заг. ред. В. А. Скуратівського, В. П. Трощинського. Київ; Львів : НАДУ, 2012. 368 с. URL: akademy. gov.ua/NMKD/library (дата звернення 20.09.2020). 15. Закон України «Про пенсійну реформу». URL: www.pfu.gov.ua (дата звернення 23.09.2020). 16. Пенсійна реформа від 22.06 .2017 р. №6614. Урядовий портал. URL: https//www.kmu.gov.ua/diyalnis (дата звернення 20.09.2020). 17. Державна служба статистики URL: https://www.googl.com.ua (дата звернення 20.09.2020). 18. Закірова С. Законопроект «Про накопичувальний рівень пенсійної системи в Україні»: оцінка експертів та фахівців. Громадська думка про правотворення. 2019. № 8 (173). C. 3-11. URL: http://nbuviap.gov.ua/index.php?option=com (дата звернення 25.09.2020). 19. Гітіс Т. П., Чемерис С. Т., Антонова В. І., Носаньова А. С. Дослідження сучасного рівня соціального захисту населення в Україні. Економічний вісник Донбасу. 2020. № 1 (59). С. 116-122. doi: 10.12958/ 1817-3772-2020-1(59)-116-122.

\section{References}

1. Vyshnevska O. A. (2016). Pensiina reforma: zarubizhnyi dosvid dlia Ukrainy. Aspekty publichnoho upravlinnia [Pension reform: foreign experience for Ukraine. Aspects of public administration]. Mekhanizmy publichnoho upravlinnia - Mechanisms of public administration, 8 (34), pp. 42-48. doi:10.15421/151639 [in Ukrainian].

2. Hrabovska H. M., Zaika V. P. (2020). Nakopychuvalna pensiina systema yak skladova nederzhavnoho pensiinoho fondu [Accumulative pension system as a component of non-state pension fund]. Molodyi vchenyiYoung scientist, 1 (77), pp. 21-25. doi: https: //doi.org/10.32839/2304-5809/2020-1-77-5 [in Ukrainian].

3. Pikus R. V., Khemii A. S. (2017). Reformuvannia system pensiinoho strakhuvannia krain Zakhidnoi Yevropy [Reforming the pension insurance systems of Western Europe]. Ekonomichnyi analiz - Economic analysis, Vol. 
27, No. 1, pp. 131-138. Ternopil, Publishing and Printing Center of Ternopil National Economic University «Ekonomichna dumka», Doi: 10.35774/econa [in Ukrainian].

4. Kirian T. (2006). Pidvyshchennia stymuliuiuchoi roli pensiinoi systemy v Ukraini [Increasing the stimulating role of the pension system in Ukraine]. Ukraina: aspekty pratsi - Ukraine: aspects of work, 8, pp. 15-20 [in Ukrainian].

5. Shapoval M. S., Kotsiuba O. V., Reznikova Yu. S. (2005). Doslidzhennia vplyvu zaprovadzhennia nakopychuvalnoi skladovoi derzhavnoi systemy pensiinoho strakhuvannia na pidvyshchennia rivnia sotsialnoho zakhystu naselennia v Ukraini [Research of influence of introduction of accumulative component of the state system of pension insurance on increase of level of social protection of the population in Ukraine]. Sotsialnyi zakhyst Social protection, 12, pp. 34-39 [in Ukrainian].

6. Nakopychuvalnyi riven pensii: chomu tse ne pratsiuie $\mathrm{v}$ Ukraini? [Accumulative pension level: why does it not work in Ukraine?]. vseprogroshi.com.ua. Retrieved from http://vseprogroshi.com.ua/nakopichuvalnij-riven-pensi\%D1\%97-chomu-ce-ne-pracyuye-vukra\%D1\%97ni.html [in Ukrainian].

7. Staverska T. O., Shevchuk. I. L. (2017). Etapy pensiinoi reformy v Ukraini [Stages of pension reform in Ukraine]. Ekonomika i suspilstvo - Economy and society, 13. Retrieved from http://www.economyandsociety.in.ua/ journal/13_ukr/204.pdf [in Ukrainian].

8. Pensiina reforma vid 15.12.2005 r. \#525-r [Pension reform of 15.12.2005 25525-r.]. Government portal. Retrieved from https//www.kmu.gov.ua/npas/25 [in Ukrainian].

9. Yakisni zminy, shcho vidbuvaiutsia vzhe sohodni [Qualitative changes taking place today]. Government portal. Retrieved from https://www.kmu.gov.ua/diyalnist/reformi [in Ukrainian].

10. Pensiinyi Fond Ukrainy [Pension Fund of Ukraine]. Retrieved from https://www.pfu.gov.ua/od/ 166068-stazh-neobhidnyj-dlya-pryznachennya-pensiyi-za -vikom/ [in Ukrainian].

11. Mastiuhina H. Pensiina reforma: osoblyvosti pryznachennia pensii [Pension reform: features of pensions]. (n.d.). Retrieved from http://uteka.ua/ua/publication [in Ukrainian].

12. Minimalna pensiia na 2019-2020 roky v Ukraini [The minimum pension for 2019-2020 in Ukraine]. Retrieved from https://www/profiwins.com [in Ukrainian].

13. Pro pensiine zabezpechennia: Zakon Ukrainy vid 05.11.1991 r. № 1788-XII [On pension provision: Law of Ukraine of November 5, 1991 № 1788-XII]. Retrieved from https://www/pfu.gov.ua zt13204 [in Ukrainian].

14. Skurativskyi V. A., Troshchynskyi V. P., Sytnyk P. K. et al. (2012)/ Reformuvannia sotsialnoi polityky v Ukraini: problemy ta perspektyvy [Reforming social policy in Ukraine: problems and prospects]. Kyiv; Lviv, NADU. 368 p. Retrieved from akademy.gov.ua/NMKD/ library [in Ukrainian].

15. Zakon Ukrainy «Pro pensiinu reformu» [Law of Ukraine "On Pension Reform"]. Retrieved from www.pfu.gov.ua [in Ukrainian].

16. Pensiina reforma vid 22.06.2017 r. №6614 [Pension reform dated 22.06.2017 №6614]. Government portal.
Retrieved from https//www.kmu.gov.ua/diyalnis [in Ukrainian].

17. Derzhavna sluzhba statystyky Ukrainy [State Statistics Service of Ukraine]. (n.d.). ukrstat.gov.ua. Retrieved from http://www.ukrstat.gov.ua/ [in Ukrainian].

18. Zakirova C. (2019). Zakonoproekt «Pro nakopychuvalnyi riven pensiinoi systemy v Ukraini»: otsinka ekspertiv ta fakhivtsiv [Bill "On the accumulative level of the pension system in Ukraine": assessment of experts and specialists]. Hromadska dumka pro pravotvorennia - Public opinion on lawmaking, 8 (173), pp. 3-11. Retrieved from http://nbuviap.gov.ua/index.php?option=com [in Ukrainian].

19. Gitis, T. P., Chemerys, Ye. T., Antonova, V. I., Nosanyova, A. S. (2020). Doslidzhennia suchasnoho rivnia sotsialnoho zakhystu naselennia $\mathrm{v}$ Ukraini [Study of the Current Level of Social Protection of the Population in Ukraine]. Ekonomichnyi visnyk Donbasu - Economic Herald of the Donbas, 1 (59), pp. 116-122. doi: 10.12958/ 1817-3772-2020-1(59)-116-122 [in Ukrainian].

Познякова О. О., Панчук Н. В., Бурцева О. С. Аналіз реформування пенсійної системи України: проблеми реалізації та перспективи розвитку

У статті розглянуто сучасні проблеми пенсійної системи в Україні, шляхи подолання та напрями їі вдосконалення. Розглянуто загальнообов'язкову накопичувальну систему пенсійного забезпечення. Проаналізовано переваги накопичувальної системи, принципи нарахування пенсії, права на пенсію, пенсії за віком, перерахування пенсії, мінімальний та максимальний розмір пенсії під час реформ. Проаналізовано зміни до деяких законодавчих актів України щодо підвищення пенсії. У статті обгрунтовано стратегічні напрями стосовно вдосконалення пенсійної реформи України. Наразі постійний моніторинг досягнення стратегічних цілей реформи пенсійної системи та пенсійного забезпечення та прийняття грунтовних рішень стосовно подолання стратегічних розривів доволі актуальне питання та потребує подальшого дослідження.

Ключові слова: пенсійна система забезпечення, пенсії, пенсійна реформа, пенсійний вік, накопичувальна система.

Poznyakova O., Panchuk N., Burtseva O. Analysis of Reforming the Pension System of Ukraine: Implementation Problems and Development Prospects

Pension provision is an element of the pension system that ensures sustainable socio-economic development of the state as a whole. The article discusses the current problems of the pension system in Ukraine, ways to overcome and directions for its improvement. Determination of the further development and reform of the pension system aimed at ensuring the financial stability of the solidarity system. Introduction of the development of the pension system, taking into account the peculiarities of the current situation in the country, ways of reforming social insurance. The compulsory accumulative pension system is considered. Its introduction to retirees for two centuries. The advantages of the funded system, what it is based on, and its main contingent of citizens are analyzed. Principles of pension accrual, pension entitlements, old-age pensions, 
pension transfer, minimum and maximum pension in the course of reforms. Analyzed, introduced by introducing amendments to some legislative acts of Ukraine regarding the increase in pensions. The demographic state of the population is considered. The article proves that the main strategic directions for improving the pension reform is the introduction of changes in the demography of the population; percentage of ERUs, when calculated for each entrepreneur separately (respectively, from the group of an individual entrepreneur to the type of activity); open your deposit account for the savings system in the public domain; to enable pensioners to work (to improve their knowledge with practitioners, to provide an opportunity to work with modern equipment, programs) to determine the dates for the introduction of the second level and the age category of participants; to establish and improve the work of the organization of pension provision; to show confidence in the reforms of the Pension Fund bodies to the population.

Nowadays, constant monitoring of the achievement of the strategic goals of the reform of the pension system and pension provision and the adoption of fundamental decisions to overcome strategic gaps is quite an urgent issue and requires further research.

Keywords: pension system, pensions, pension reform, pensioners, pension reform, pensioners.
Познякова О. О., Панчук Н. В., Бурцева Е. Е. Анализ реформирования пенсионной системы Украины: проблемы реализации и перспективы развития

В статье рассмотрены современные проблемы пенсионной системы в Украине, пути преодоления и направления ее совершенствования. Рассмотрена общеобязательная накопительная система пенсионного обеспечения. Проанализированы преимущества накопительной системы, принципы начисления пенсии, права на пенсию, пенсии по возрасту, перерасчет пенсии, минимальный и максимальный размер пенсии в ходе реформ. Проанализированы введенные изменения в некоторые законодательные акты Украины относительно повышения пенсии. Обоснованы основные стратегические направления по совершенствованию пенсионной реформы Украины. Постоянный мониторинг стратегических целей реформы пенсионной системы и пенсионного обеспечения и принятие фундаментальных решений по преодолению стратегических разрывов довольно актуальный вопрос и требует дальнейшего исследования.

Ключевые слова: пенсионная система обеспечения, пенсии, пенсионная реформа, пенсионный возраст, накопительная система.

Received by the editors: 02.10 .2020 and final form 29.12.2020 